\title{
Persepsi Petani terhadap Kompetensi Penyuluh Pertanian di Kecamatan Payakumbuh, Kabupaten Lima Puluh Kota
}

\section{Farmers Perceptions on the Competence of Agricultural Extension Workers in Payakumbuh District, Lima Puluh Kota Regency}

\author{
Mega Amelia Putri*), Veronice, Gusdea Ananda \\ Politeknik Pertanian Negeri Payakumbuh, Sumatera Barat 26271, Indonesia \\ ${ }^{*}$ E-mail korespondensi: lia.politani@gmail.com \\ Diterima: 21 Juni 2021 | Disetujui: 17 Januari 2022 | Publikasi Online: 21 Januari 2022
}

\begin{abstract}
Agricultural extension is a lesson for the main actors and business actors so that they can help themselves in obtaining information related to the sustainability of their farming business. This study aims to: 1) analyze farmers perceptions of the competence of agricultural instructors, 2) analyze the relationship between farmer characteristics and extension activities with the level of farmers perceptions of agricultural instructor competencies based on the Regulation of the Minister of Agriculture No: 55/Permentan/KP. 120/7/2007. This study used a survey method with a total of 39 respondents. The results of descriptive and inferential analysis found that farmers had low perceptions of the competency level of agricultural extension workers. Extension workers are considered not optimal in carrying out their roles according to their duties and responsibilities. The factors that significantly influence the level of farmers perceptions of the competence of agricultural extension workers are the involvement, intensity and interaction of farmers in extension activities. This shows that the more frequent the involvement, the intensity of the meetings and the interaction of farmers with agricultural extension workers, the level of farmers perceptions of the main extension activities, extension planning, extension programs, application of extension methods, farmer self-help development, regional development, as well as the development of cooperative relationships with government agencies and non-government is higher.
\end{abstract}

Keywords: Agricultural extension, internal and eksternal factors, participation, perception

\begin{abstract}
ABSTRAK
Penyuluhan pertanian adalah suatu pembelajaran untuk pelaku utama maupun pelaku usaha agar dapat membantu dirinya sendiri dalam memperoleh informasi yang berkaitan dengan keberlangsungan usaha taninya. Penelitian ini bertujuan: 1) menganalisis persepsi petani terhadap kompetensi penyuluh pertanian, 2) menganalisis hubungan karakteristik petani dan kegiatan penyuluhan dengan tingkat persepsi petani tentang kompetensi penyuluh pertanian berdasarkan Peraturan Menteri Pertanian No:55/Permentan/KP.120/7/2007. Penelitian ini menggunakan metode survei dengan jumlah responden sebanyak 39 orang. Hasil analisis secara deskriptif dan inferensial menemukan bahwa petani memiliki persepsi rendah terhadap tingkat kompetensi penyuluh pertanian. Penyuluh dinilai belum maksimal dalam menjalankan peran mereka sesuai tugas dan tanggung jawabnya. Faktor-faktor yang berpengaruh nyata dengan tingkat persepsi petani terhadap kompetensi penyuluh pertanian adalah keterlibatan, intensitas dan interaksi petani pada kegiatan penyuluhan. Hal ini menunjukkan bahwa semakin sering keterlibatan, intensitas pertemuan dan interaksi petani dengan penyuluh pertanian maka tingkat persepsi petani terhadap kegiatan utama penyuluhan, perencanaan penyuluhan, program penyuluhan, penerapan metode penyuluhan, pengembangan swadaya petani, pengembangan wilayah, serta pengembangan hubungan kerjasama dengan lembaga pemerintah dan non pemerintah semakin tinggi.
\end{abstract}

Kata kunci: Faktor internal dan eksternal petani, partisipasi, penyuluh pertanian, persepsi

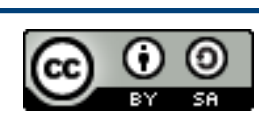

Content from this work may be used under the terms of the Creative Commons Attribution-ShareAlike 4.0 International. Any further distribution of this work must maintain attribution to the author(s) and the title of the work, journal citation and DOI.

Published under Department of Communication and Community Development Science, IPB University and in association with Perhimpunan Ahli Penyuluhan Pembangunan Indonesia.

E-ISSN: 2442-4110 | P-ISSN: 1858-2664 


\section{PENDAHULUAN}

Penyuluh pertanian dituntut untuk mampu menggerakkan masyarakat dan memberdayakan petani dan memberikan informasi dalam keberlangsungan kegiatan pertanian yang dilakukan oleh petani.

"Penyuluh pertanian adalah proses pembelajaran bagi pelaku utama serta pelaku usaha agar mereka mau dan mampu menolong dirinya dalam mengakses informasi pasar, teknologi, permodalan, dan sumber daya lainnya sebagai upaya untuk meningkatkan produktivitas, efisiensi usaha, pendapatan, dan kesejahteraan, serta meningkatkan kesadaran dalam pelestarian lingkungan hidup" (Undang-Undang RI, 2006).

Pengembangan kelompok tani memiliki peran strategis untuk meningkatkan produktivitas usaha mereka. Selain dari kegiatan yang diberikan oleh penyuluh, peningkatan kualitas petani dapat dilakukan melalui kerjasama yang baik antara penyuluh dengan kelompok tani (Mbeche et al., 2021; Nettle, 2021; Nurfaidah \& Rusdiyana, 2020). Hal ini mengharuskan penyuluh untuk memiliki kemampuan dalam mentransfer informasi dan inovasi dengan cara yang mudah dipahami oleh petani disetiap kegiatan penyuluhan pertanian (Saridewi et al., 2020; Sylla et al., 2019). Sehingga, pembinaan yang dilakukan penyuluh kepada kelompok tani berjalan secara baik dan lancar. Selain itu, dalam menjalankan programnya, penyuluh membutuhkan partisipasi dari anggota kelompok tani yang telah dibentuk (Jalaluddin \& Adjie, 2020; Lahidjun et al., 2020; Nurmayasari et al., 2020).

Petani sebagai pelaku utama dalam kegiatan produksi memerlukan pengembangan inovasi teknologi untuk meningkatkan produktivitas hasil yang diperoleh. Hal ini tentu saja bergantung terhadap kemampuan petani dalam menyerap inovasi teknologi secara cepat dan setuju. Adapun faktor-faktor yang mempengaruhi persepsi petani terhadap inovasi teknologi bersumber dari faktor internal dan eksternal. Hasil studi Mulieng et al., (2018) menunjukkan bahwa karakteristik petani yang berhubungan dengan kompetensi penyuluh pertanian tanaman pangan adalah status kepemilikan lahan terhadap penerapan metode penyuluhan dan faktor eksternal dapat berupa aspek fisik, non fisik dan lingkungan.

Permasalahan yang dihadapi petani di Kecamatan Payakumbuh Kabupaten Lima Puluh Kota berkaitan dengan peningkatan kualitas tenaga penyuluh yang tercermin pada kinerja penyuluh pertanian dalam membina kelompok tani di daerah tersebut. Kelompok tani yang terdaftar dan tersebar di Kecamatan Payakumbuh terdiri dari 104 kelompok tani sedangkan ketersediaan tenaga kerja penyuluh hanya 6 orang. Apabila dilihat dari ketersediaan tenaga kerja penyuluh tentunya tidak sebanding dengan banyaknya jumlah kelompok tani yang tersebar di Kecamatan Payakumbuh. Kondisi tenaga kerja penyuluh di lapangan yang terbatas menyebabkan kesenjangan petani terhadap perubahan informasi yang cepat dan dapat menurunkan efektivitas penyuluhan (Sirnawati, 2020).

Usaha yang dapat dilakukan dalam melihat kinerja yang diberikan oleh penyuluh terhadap petani adalah dengan mengevaluasi kinerja penyuluh pertanian (Bahua, 2015; Gitosaputro \& Listiana, 2018). Pedoman dalam penilaian kinerja penyuluh pertanian berdasarkan ketentuan Menteri Pertanian RI Nomor: 5/Permentan/KP.120/7/2007 tertanggal 25 juli 2007 terkait acuan penilaian bagi penyuluh pertanian berprestasi. Indikator penilaian prestasi kerja dan karya khusus antara lain: 1) kegiatan utama bagi penyuluh, 2) perencanaan bagi penyuluh, 3) program penyuluhan, 4) penyusunan materi penyuluhan, 5) penerapan metode penyuluhan, 6) pengembangan swadaya dan swakarsa bagi petani, 7) pengembangan wilayah, 8) pengembangan profesi penyuluh, 9) pengembangan hubungan kerjasama dengan lembaga pemerintah dan non pemerintah. Seluruh indikator menjadi fokus pengamatan terhadap kompetensi penyuluh pertanian.

Penyuluh harus tahu bagaimana persepsi petani, agar nantinya penyuluh bisa melakukan tindakan sesuai kebutuhan petani. Persepsi petani dapat memberikan gambaran dan pengukuran yang bermanfaat untuk penyuluh dalam melakukan suatu evaluasi pada kualitas layanannya terhadap berbagai kebutuhan petani. Oleh karena itu, penelitian ini bertujuan untuk menganalisis persepsi petani terhadap kompetensi penyuluh pertanian di Kecamatan Payakumbuh Kabupaten Lima Puluh Kota, agar nantinya penyuluh dapat melakukan evaluasi dan memberikan tindakan sesuai dengan kebutuhan petani.

\section{METODE}

Penelitian menggunakan metode survey. Lokasi penelitian di Kecamatan Payakumbuh Kabupaten Lima Puluh Kota. Populasi dalam penelitian ini adalah 254 petani. Penentuan sampel secara 
proporsional random sampling sebanyak 39 responden dari 3 nagari/kelurahan pada Kecamatan Payakumbuh dengan pertimbangan memiliki kelompok petani terbanyak pada kelas "lanjut". Hal ini diharapkan penilaian petani terhadap penyuluh dapat tergambarkan dengan tepat dan akurat. Penelitian dilakukan pada Bulan April sampai Mei 2021. Jenis data yang dikumpulkan yaitu data primer dan sekunder. Data primer terdiri atas (1) karakteristik petani seperti umur, tingkat pendidikan, luas lahan, status kepemilikan lahan dan pengalaman berusaha tani, (2) persepsi petani terhadap kompetensi penyuluh pertanian sesuai pedoman penilaian penyuluh pertanian yang diterbitkan oleh Menteri Pertanian No: 55/Permentan/KP.120/7/2007. Instrumen penelitian berupa kuesioner yang disusun secara sistematis. Data dianalisis secara deskriptif dan inferensial. Secara deskriptif berdasarkan temuan dilapangan dan disimpulkan berdasarkan persepsi petani. Pengukuran persepsi menggunakan skala likert yang dibedakan menjadi 3 skala yaitu skala 1 Tidak Setuju (TS), Skala 2 Kurang Setuju (KS), Skala 3 Setuju (S). Secara inferensial data dianalisis menggunakan uji statistik non parametrik, yakni korelasi Rank Spearman bertujuan melihat hubungan antara variabel faktor karakteristik petani dengan persepsi petani terhadap kompetensi penyuluh pertanian.

\section{HASIL DAN PEMBAHASAN}

\section{Profil Petani di Kecamatan Payakumbuh}

Petani di Kecamatan Payakumbuh sebagian besar merupakan petani yang mengusahakan tanaman pangan yaitu padi dengan luas panen sebesar 5.086,00 Ha dan jumlah produksinya sebesar 222.572,00 ton. Petani berjenis kelamin perempuan lebih mendominasi (56\%) dibandingkan laki-laki (44\%). Hal tersebut dikarenakan perempuan dalam melakukan usahatani dituntut untuk lebih cekatan, lincah dan gesit dalam melakukan suatu tindakan di pertanian. Hal ini dikarenakan perempuan menjadi agen yang cukup penting dalam ketahanan dan kesejahteraan keluarga. Selain itu, kegiatan usahatani ini merupakan usaha turun temurun dalam satu keluarga, sehingga dalam pengelolaannya tergolong sederhana dan mayoritas menggunakan tenaga kerja dalam keluarga. Walaupun, potensi komoditi pertanian terutama padi di daerah ini memiliki prospek yang tinggi untuk dikembangkan. Namun, pelaku usahatani masih menghadapi berbagai kendala.

Kendala usahatani di Kecamatan Payakumbuh Kabupaten Lima Puluh Kota umumnya disebabkan karena aspek kurangnya modal dalam mengelola usahatani, kurangnya akses informasi dalam memasarkan produk pertanian, kurangnya ketersediaan saprodi juga pengendalian hama yang belum memadai dan berbagai kendala lainnya yang dirasakan oleh petani. Kekurangan modal menyebabkan kurangnya masukan yang diberikan sehingga menimbulkan resiko kegagalan atau rendahnya hasil yang akan diterima. Upaya yang dapat dilakukan adalah dengan memanfaatkan kelompok tani sebagai wadah dalam mengoptimalkan potensi yang tersedia. Hal ini tentu saja perlu keterlibatan pemerintah melalui penyediaan tenaga kerja profesional di bidang penyuluhan pertanian. Namun, ketersediaan penyuluh pertanian yang ada di Kecamatan Payakumbuh Kabupaten Lima Puluh Kota masih terbatas. Hal ini dikhawatirkan akan menghambat keberlanjutan dan pengembangan usaha petani di masa yang akan datang.

\section{Karakteristik Petani Responden}

Menurut Bahua, 2015; Banunaek et al., (2020) penyebab keberhasilan usahatani antara lain berasal dari faktor internal dan faktor eksternal. Kedua faktor ini saling mempengaruhi. Faktor internal petani yang diteliti terdiri atas: umur, tingkat pendidikan, status kepemilikan lahan dan interaksi sosial petani. Faktor eksternal petani terdiri atas: faktor keterlibatan dalam kelompok tani, intensitas penyuluhan dan interaksi sosial petani.

\section{Umur}

Umur adalah umur responden saat melakukan penelitian di Kecamatan Payakumbuh. Umur berkaitan dengan kemampuan petani dalam mengambil keputusan dan menerima inovasi baru dari penyuluh pertanian. Hal ini sesuai pendapat Zulfikar et al., (2018) yang menyatakan bahwa umur berkaitan dengan daya serap dan pemahaman inovasi baru dalam melakukan usahatani. 
Tabel 1. Distribusi Faktor Internal dan Eksternal Responden dalam Kelompok Tani

\begin{tabular}{|c|c|c|c|c|}
\hline \multirow{2}{*}{$\begin{array}{c}\text { No. } \\
1 .\end{array}$} & \multicolumn{4}{|c|}{ Faktor Internal Petani } \\
\hline & Umur (Tahun) & Kategori & $\mathrm{N}$ & $\%$ \\
\hline & $>60$ tahun & Muda & 5 & 12.8 \\
\hline & 41-60 tahun & Dewasa & 29 & 74.4 \\
\hline & $<40$ tahun & Tua & 5 & 12.8 \\
\hline & Total & & 39 & 100 \\
\hline \multirow[t]{5}{*}{2.} & Tingkat Pendidikan & Kategori & $\mathrm{N}$ & $\%$ \\
\hline & Tamat SD & Rendah & 6 & 15.4 \\
\hline & Tamat SMP & Sedang & 12 & 30.8 \\
\hline & Tamat SMA/S1 & Tinggi & 21 & 53.8 \\
\hline & Total & & 39 & 100 \\
\hline \multirow[t]{5}{*}{3.} & Status Kepemilikan Lahan & Kategori & $\mathrm{N}$ & $\%$ \\
\hline & Sewa & Rendah & 12 & 30.8 \\
\hline & Milik Sendiri & Sedang & 23 & 59.0 \\
\hline & Lainnya & Tinggi & 4 & 10.3 \\
\hline & Total & & 39 & 100 \\
\hline \multirow[t]{5}{*}{4.} & Faktor Status Pengalaman Berusahatani & Kategori & $\mathrm{N}$ & $\%$ \\
\hline & $<10$ Tahun & Rendah & 10 & 25.6 \\
\hline & 11-20 Tahun & Sedang & 12 & 30.8 \\
\hline & $>20$ Tahun & Tinggi & 17 & 43.6 \\
\hline & Total & & 39 & 100 \\
\hline No. & & sternal Petani & & \\
\hline \multirow[t]{5}{*}{1.} & Faktor Keterlibatan dalam Kelompok Tani & Kategori & $\mathrm{N}$ & $\%$ \\
\hline & Tidak Pernah & Rendah & 3 & 7.7 \\
\hline & $1-3$ kali & Sedang & 12 & 30.8 \\
\hline & $>3$ kali & Tinggi & 24 & 61.5 \\
\hline & Total & & 39 & 100 \\
\hline \multirow[t]{5}{*}{2.} & Intensitas Penyuluhan & Kategori & $\mathrm{N}$ & $\%$ \\
\hline & Tidak Pernah & Rendah & 3 & 7.7 \\
\hline & $1-5$ kali & Sedang & 17 & 43.6 \\
\hline & $>5$ kali & Tinggi & 19 & 48.7 \\
\hline & Total & & 39 & 100 \\
\hline \multirow[t]{5}{*}{3.} & Interaksi Sosial Petani & Kategori & $\mathrm{N}$ & $\%$ \\
\hline & Tidak Pernah & Tidak Pernah & 4 & 10.3 \\
\hline & 1-2 pihak & Kadang-Kadang & 22 & 56.4 \\
\hline & $>3$ pihak & Sering & 13 & 33.3 \\
\hline & Total & & 39 & 100 \\
\hline
\end{tabular}

Sumber: Analisis Data Primer (2021)

Pada Tabel 1, petani memiliki umur paling dominan antara 41-60 tahun dengan tingkat persentasi $74,4 \%$. Kondisi ini menggambarkab bahwa sebagian besar responden merupakan petani dengan kategori dewasa dan berada pada usia produktif untuk mengikuti kegiatan penyuluhan pertanian. Menurut Zulfikar et al., (2018) kondisi fisik dan mental yang kuat menjadi modal utama untuk mencoba inovasi- inovasi baru yang disampaikan oleh penyuluh, sehingga dimasa yang akan datang peluang keberhasilan dan kesuksesan penyuluhan akan lebih besar.

Selanjutnya juga dapat dilihat petani yang berusia $>60$ tahun kategori tua yakni 5 orang dengan persentase $12,8 \%$. Semakin tua usia biasanya semakin lambat dalam mengadopsi inovasi baru dibidang pertanian (Setyasih et al., 2020). Selain itu pada lokasi penelitian ini petani yang berusia < 40 tahun kategori muda berjumlah 5 orang atau dengan persentase 12,8 persen. Hasil ini menyimpulkan bahwa generasi muda tidak begitu tertarik dalam bidang pertanian dan lebih memilih bekerja pada sektor non pertanian, yaitu bekerja sebagai buruh, PNS, pegawai swasta, pedagang dan sebagainya, 


\section{Tingkat Pendidikan Formal}

Salah satu karakteristik responden yang berperan penting dalam pemahaman dan keberhasilan usahatani yang sedang dilakukan, yaitu tingkat pendidikan. Kategori yang digunakan berdasarkan jenjang pendidikan terakhir. Menurut Mardikanto et al., (2013) menyatakan bahwa pendidikan petani umumnya mempengaruhi cara dan pola pikir petani dalam mengelola usahatani. Kemampuan petani dalam proses pengambilan keputusan berbanding lurus dengan tingkat pendidikan seseorang. Distribusi responden berdasarkan tingkat pendidikan formal petani didominasi oleh lulusan SMA/S1 atau berkategori tinggi yaitu sebanyak 21 responden dengan persentase 53,8 persen. Menurut Widakdo et al., (2021) "Salah satu aset inti dalam masyarakat adalah prestasi pendidikan individu. Berdasarkan hal tersebut dapat terlihat bahwa temuan penelitian menunjukkan bahwa tingkat pendidikan formal tergolong tinggi dan juga membantu petani dalam pengambilan keputusan dan mengadopsi inovasi teknologi di bidang pertanian menjadi lebih baik.

\section{Status Kepemilikan Lahan}

Status kepemilikan lahan ditentukan berdasarkan hak milik lahan yang diusahakan oleh petani. Hasil penelitian di lapangan, petani dengan persentase tertinggi 59,0\% dengan lahan milik sendiri. Menurut penelitian Zulfikar et al., (2018) menyatakan bahwa terdapat hubungan nyata antara status kepemilikan lahan dengan persepsi petani. Artinya, semakin tinggi tingkat kepemilikian lahan oleh petani maka akan semakin tinggi peluang petani untuk melakukan inovasi dan adopsi teknologi yang akan disampaikan oleh penyuluh pertanian.

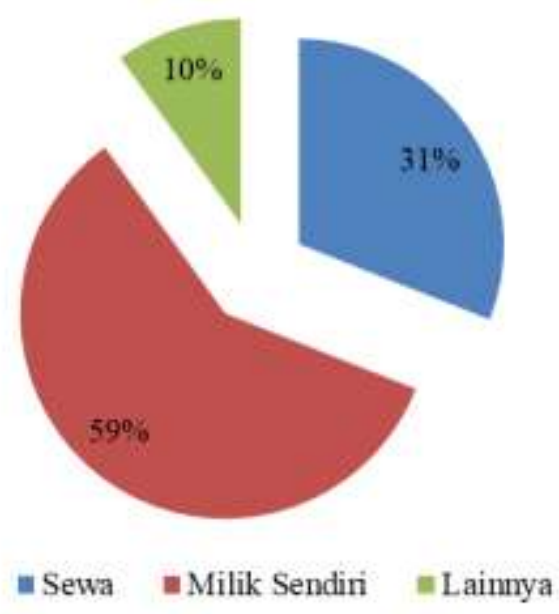

Gambar 1. Distribusi Responden Berdasarkan Status Kepemilikan Lahan Petani

\section{Pengalaman Berusahatani}

Pengalaman berusaha tani menunjukkan jangka waktu responden menggeluti bidang pertanian. Distribusi responden berdasarkan pengalaman berusahatani lebih dari 20 tahun atau berkategori tinggi. Menurut Hasan, (2000) bahwasanya jika petani mempunyai pengalaman yang relatif tinggi maka akan berhasil dalam usahataninya dan mempunyai pengetahuan, sikap dan keterampilan yang lebih baik dibandingkan dengan petani yang kurang berpengalaman. Tingginya pengalaman petani akan lebih mampu dalam mengadopsi inovasi teknologi dan untuk pengambilan keputusan dalam kegiatan usahatani.

\section{Keterlibatan dalam Kelompok Tani}

Keterlibatan petani dalam kelompok tani dalam penelitian ini adalah jumlah pertemuan rutin atau 
bulanan yang pernah diikuti oleh anggota kelompok tani. Keterlibatan petani dalam kelompok tani dalam sebanyak 24 responden atau 48,7 persen responden mengikuti lebih dari tiga kali pertemuan. Jumlah responden yang mengikuti kegiatan pertemuan rutin sebanyak 1-3 kali pertemuan atau masuk kategori sedang adalah sebanyak 12 responden atau 43,6 persen. Berdasarkan hasil penelitian di lapangan, pertemuan dilaksanakan ketika ada permasalahan dan kepentingan dalam usahatani untuk mendapatkan keputusan atau menghasilkan kesepakatan. Kondisi tersebut menunjukkan bahwa keterlibatan petani sangat penting. Hal tersebut juga dijelaskan Zulfikar et al., (2018) yang menyatakan bahwa keterlibatan petani dalam kelompok tani memiliki hubungan yang signifikan dengan persepsi petani. Semakin aktif dan seringnya petani terlibat dalam kelompok tani maka semakin baik petani dalam menilai kinerja penyuluh pertanian.

\section{Intensitas Penyuluhan}

Intensitas penyuluhan merupakan jumlah pertemuan atau kegiatan penyuluhan yang pernah diikuti oleh anggota kelompok tani atau petani selama dua tahun terakhir. Petani di Kecamatan Payakumbuh atau sebanyak 19 responden atau 48,7 persen responden petani mengikuti lebih dari lima kali penyuluhan dan tergolong kategori tinggi. Intensitas penyuluhan yang diikuti oleh petani akan mempengaruhi persepsi petani dalam penilaian kinerja penyuluh pertanian. Semakin sering mengikuti kegiatan penyuluhan maka petani akan lebih mengetahui kinerja penyuluh pertanian. Menurut Purukan et al., (2021) keberhasilan sektor pertanian salah satunya ditentukan oleh penyuluh pertanian. Penyuluh pertanian sendiri memiliki fungsi untuk membina petani dalam rangka meningkatkan produktivitas tani.

\section{Interaksi Sosial Petani}

Interaksi sosial dalam penelitian ini diukur berdasarkan interaksi petani dengan petani lainnya, interaksi petani dengan penyuluh dan interaksi petani dengan kelompok tani. Sebagian besar petani atau sebanyak 22 responden atau 56,4 persen responden petani di Kecamatan Payakumbuh memiliki tingkat interaksi sosial berkategori sedang, sedangkan 13 petani responden atau 33,3 persen memiliki tingkat interaksi sosial berkategori tinggi. Interaksi sosial petani akan mempengaruhi persepsi petani dalam penilaian kinerja penyuluh pertanian. Hal ini sesuai dengan pernyataan Saridewi et al., (2020) bahwa interaksi sosial berpengaruh terhadap persepsi karena dengan adanya interaksi antara penyuluh dan petani maka akan mampu menilai kinerja penyuluh. Semakin sering petani berinteraksi dengan berbagai pihak maka akan semakin banyak informasi yang akan mempengaruhi persepsi seseorang terhadap kinerja penyuluh.

\section{Persepsi Petani terhadap Kompetensi Penyuluh Pertanian}

Persepsi merupakan salah satu bentuk psikologis manusia yang berguna untuk merespon kehadiran dari berbagai aspek dan gejala disekitarnya. Persepsi berkaitan erat dengan sikap, karena persepsi merupakan komponen kognitif sikap. Persepsi memberikan makna pada rangsangan inderawi. Menafsirkan makna informasi inderawi tetapi juga atensi (perhatian), ekspektasi (harapan), motivasi, dan memori. Pedoman penilaian kompetensi penyuluh pertanian berdasarkan Peraturan Menteri Pertanian No.55/Permentan/KP.120/7/2007 dan dirumuskan berdasarkan persepsi petani di Kecamatan Payakumbuh, Kabupaten Lima Puluh Kota. 


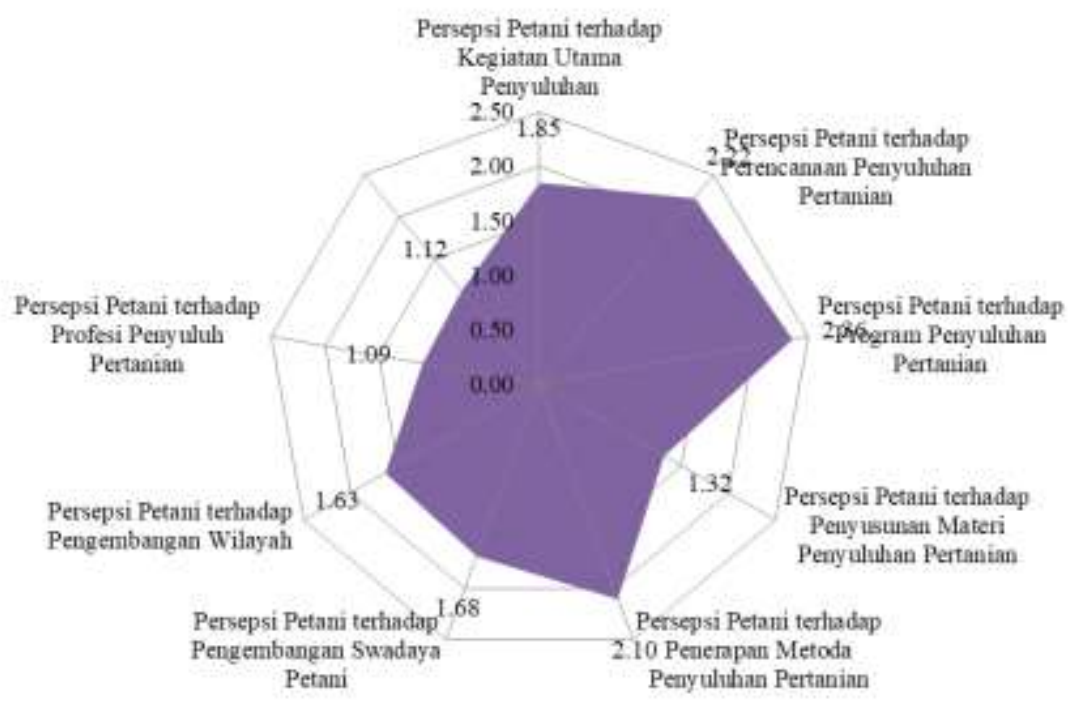

Gambar 2. Persepsi Petani terhadap Kompetensi Penyuluh Pertanian

Keterangan:

Skor $1.00-2.00=$ Rendah $(\mathrm{R})$

Skor $2.01-3.00=$ Sedang $(\mathrm{S})$

Skor $3.01-4.00=$ Tinggi $(\mathrm{T})$

Gambar 2 menunjukkan bahwa secara keseluruhan persepsi petani terhadap kompetensi penyuluh pertanian di Kecamatan Payakumbuh yang meliputi; kegiatan utama penyuluhan, program penyuluhan, pengembangan swadaya petani, pengembangan wilayah, profesi penyuluh dan pengembangan hubungan kerjasama dengan lembaga pemerintah dan non pemerintah masuk katagori rendah. Persepsi petani terhadap perencanaan penyuluh, penyusunan materi, dan metode penyuluhan termasuk katagori sedang. Penilaian pernyataan yang disampaikan responden secara keseluruhan memberikan jawaban dengan katagori rendah terhadap pernyataan yang ajukan. Artinya bahwa penyuluh memiliki tingkat kompetensi yang rendah dalam menjalankan sembilan kompetensi yang diukur. Secara rinci penjelasan masing-masing indikator diuraikan lebih lanjut.

\section{Persepsi Petani terhadap Kegiatan Utama Penyuluhan}

Kegiatan praktik, proses bimbingan, pelatihan dan kunjungan merupakan indikator dalam menjalankan kegiatan utama penyuluhan. Tabel 2 pada kegiatan utama penyuluhan, tugas dan tanggungjawab penyuluh dalam menjalankan tugas utamanya dinilai oleh persepsi petani masuk katagori rendah. Hal ini dikarenakan menurut petani penyuluh belum intensif dalam menjalankan kegiatan kunjungan dan kegiatan praktek bersama petani. Kegiatan praktik merupakan kegiatan belajar langsung di lapangan mengenai suatu inovasi yang diberikan oleh penyuluh pertanian. 
Tabel 2. Persepsi Petani terhadap Kegiatan Utama Penyuluh Pertanian

\begin{tabular}{|c|c|c|c|c|c|c|}
\hline \multirow{2}{*}{ No. } & \multirow{2}{*}{ Pernyataan } & $\mathbf{T S}$ & KS & $\mathbf{S}$ & \multirow{2}{*}{ Persepsi } & \multirow{2}{*}{ Keterangan } \\
\hline & & 1 & 2 & 3 & & \\
\hline Y1 & Persepsi Petani terhadap Kegiatan Utama Penyuluhan & & & & & \\
\hline $\mathrm{X} 1.1$ & $\begin{array}{l}\text { Penyuluh melakukan praktek/kaji terap bersama } \\
\text { petani }\end{array}$ & 17 & 13 & 9 & 1.79 & Rendah \\
\hline $\mathrm{X} 1.2$ & Penyuluh melakukan bimbingan kepada petani & 12 & 11 & 16 & 2.10 & Sedang \\
\hline $\mathrm{X} 1.3$ & Penyuluh melakukan pelatihan kepada petani & 20 & 15 & 4 & 1.59 & Sedang \\
\hline \multirow[t]{2}{*}{$\mathrm{X} 1.4$} & $\begin{array}{l}\text { Penyuluh tidak pernah melakukan kunjungan kepada } \\
\text { petani }\end{array}$ & 15 & 13 & 11 & 1.90 & Rendah \\
\hline & Rata-rata & 64 & 52 & 40 & 1.85 & Rendah \\
\hline
\end{tabular}

Kegiatan bimbingan dan pelatihan dalam kegiatan utama penyuluhan dinilai petani sudah masuk katagori sedang. Artinya adalah peningkatan kapasitas petani yang didampingi oleh penyuluh untuk meningkatkan pengetahuan, sikap dan keterampilan petani dalam pengembangan usaha pertanian sudah dijalankan. Sebagai contoh kelatihan dalam kegiatan utama penyuluhan diterapkan dengan metode SL (Sekolah Lapang) (Hanan et al., 2019). Biasanya SL yang diikuti oleh petani di Kecamatan Payakumbuh seperti SL pada komoditi jagung dan padi. Kunjungan penyuluh kepada petani tergolong rendah, dikarenakan penyuluh jarang mendatangi petani atau kelompok tani.

\section{Persepsi Petani terhadap Perencanaan Penyuluhan Pertanian}

Penilaian yang dilakukan kelompok tani terhadap kinerja penyuluh terkait data potensi wilayah sasaran, data masalah lokasi dan data monografi dalam perencanaan penyuluhan pertanian dapat dilihat pada Tabel 3.

Tabel 3. Persepsi Petani terhadap Perencanaan Penyuluh Pertanian

\begin{tabular}{|c|c|c|c|c|c|c|}
\hline \multirow{2}{*}{ No. } & \multirow{2}{*}{ Pernyataan } & TS & $\mathbf{K S}$ & $\mathbf{S}$ & \multirow{2}{*}{ Persepsi } & \multirow{2}{*}{ Keterangan } \\
\hline & & 1 & 2 & 3 & & \\
\hline $\mathrm{Y} 2$ & $\begin{array}{l}\text { Persepsi Petani terhadap Perencanaan Penyuluhan } \\
\text { Pertanian }\end{array}$ & & & & & \\
\hline $\mathrm{X} 2.1$ & $\begin{array}{l}\text { Penyuluh memiliki data potensi wilayah sasaran } \\
\text { penyuluhan }\end{array}$ & 14 & 3 & 22 & 2.21 & Sedang \\
\hline $\mathrm{X} 2.2$ & $\begin{array}{l}\text { Penyuluh memiliki data masalah lokasi sasaran } \\
\text { penyuluhan }\end{array}$ & 14 & 3 & 22 & 2.21 & Sedang \\
\hline \multirow[t]{2}{*}{$\mathrm{X} 2.3$} & $\begin{array}{l}\text { Penyuluh memiliki data monografi lokasi } \\
\text { penyuluhan }\end{array}$ & 13 & 3 & 23 & 2.26 & Sedang \\
\hline & Rata-rata & 41 & 9 & 67 & 2.22 & Sedang \\
\hline
\end{tabular}

Petani memberikan penilaian terhadap perencanaan penyuluhan pertanian dinilai sedang, dimana tingkat penilaian pada masing-masing indikator diperoleh dengan kategori Setuju terbanyak. Berdarkan hasil wawancara petani mengetahui adanya data perencanaan penyuluhan, dengan mendatangi kantor wali nagari untuk mendapatkan akses informasi untuk perencanaan penyuluhan yang akan dilakukan.

Sebagai penyuluh pertanian, tentunya harus memahami tentang pelaksanaan penyuluhan secara profesional yang diawali dengan kegiatan perencanaan yang baik dan benar. Hal ini sesuai pendapat yang menyatakan bahwa.

"Program pembangunan pertanian akan lebih mudah dipahami dan diadopsi oleh petani, jika para penyuluh mengetahui secara lebih mendalam dan terukur seberapa besar pentingnya program tersebut bagi petani. Hal ini dapat dilakukan oleh penyuluh dengan melibatkan petani pada semua tahapan proses perencanaan program penyuluhan pertanian (Bahua, 2015).

Berdasarkan hal tersebut, kegiatan perencanaan penyuluhan pertanian diawali dengan melaksanakan identifikasi wilayah yang berorientasi agribisnis, diketahuinya potensi dan data masalah yang melibatkan petani serta solusi pemecahan masalah yang akan diberikan penyuluh. 


\section{Persepsi Petani terhadap Program Penyuluhan Pertanian}

Suatu rencana kerja yang dirumuskan harus sesuai dengan kebutuhan sasaran penyuluhan. Oleh karena itu, diperlukan adanya penyusunan program penyuluhan pertanian yang dilakukan secara bersamasama baik penyuluh, petani-peternak, maupun para penentu kebijakan. Pada Tabel 4 petani memberikan penilaian terhadap program penyuluhan pertanian dengan katagori sedang, dimana indikator yang diukur adalah kemampuan penyuluh dalam menyusun programa dalam bentuk buku dan data. Berdarkan hasil wawancara petani mengetahui adanya data program penyuluhan pertanian, dengan mendatangi kantor wali negeri.

Tabel 4. Persepsi Petani terhadap Program Penyuluh Pertanian

\begin{tabular}{|c|c|c|c|c|c|c|}
\hline \multirow{2}{*}{ No. } & \multirow{2}{*}{ Pernyataan } & TS & KS & $S$ & \multirow{2}{*}{ Persepsi } & \multirow{2}{*}{ Keterangan } \\
\hline & & 1 & 2 & 3 & & \\
\hline Y3 & $\begin{array}{l}\text { Persepsi Petani terhadap Program Penyuluhan } \\
\text { Pertanian }\end{array}$ & 0 & 0 & 0 & 0 & Sedang \\
\hline \multirow[t]{2}{*}{ X3.1 } & $\begin{array}{l}\text { Penyuluh memiliki programa yang tersusun dalam } \\
\text { bentuk buku dan data }\end{array}$ & 10 & 5 & 24 & 2.36 & Sedang \\
\hline & Rata-rata & 10 & 5 & 24 & 2.36 & Sedang \\
\hline
\end{tabular}

Hal ini sesuai dengan pendapat (Bahua, 2015), yang menyatakan bahwa perencanaan program atau program penyuluhan pertanian dirumuskan oleh banyak pihak yaitu penyuluh bersama-sama masyarakat sasarannya dengan didukung oleh para spesialis, praktisi dan penentu kebijaksanaan yang berkaitan dengan upaya-upaya pembangunan masyarakat setempat.

\section{Persepsi Petani terhadap Penyusunan Materi Penyuluhan Pertanian}

Materi penyuluhan untuk mengukur penilaian kompetensi penyuluh terdiri atas dua bagian yaitu media cetak dan media eletronik. Media cetak yang sering diberikan pada petani dalam suatu penyuluhan seperti buku, poster dan brosur. Begitu juga dengan media elektronik seperti tranparansi/slide, $\mathrm{CD} /$ kaset radio, dan $\mathrm{VCD} /$ kaset. Berikut ini penilaian kinerja penyuluh terhadap penyusunan materi penyuluhan ke kelompok tani dapat dilihat pada Tabel 5.

Tabel 5. Persepsi Petani terhadap Penyusunan Materi Penyuluh Pertanian

\begin{tabular}{|c|c|c|c|c|c|c|}
\hline \multirow{2}{*}{ No. } & \multirow{2}{*}{ Pernyataan } & TS & KS & $\mathbf{S}$ & \multirow{2}{*}{ Persepsi } & \multirow{2}{*}{ Keterangan } \\
\hline & & 1 & 2 & 3 & & \\
\hline Y4 & $\begin{array}{l}\text { Persepsi Petani terhadap Penyusunan Materi Penyuluhan } \\
\text { Pertanian }\end{array}$ & & & & & \\
\hline $\mathrm{X} 4.1$ & $\begin{array}{l}\text { Penyuluh menggunakan materi penyuluhan dalam } \\
\text { bentuk media cetak (poster, brosur) }\end{array}$ & 23 & 12 & 4 & 1.51 & Rendah \\
\hline \multirow[t]{2}{*}{$\mathrm{X} 4.2$} & $\begin{array}{l}\text { Penyuluh menggunakan materi penyuluhan dalam } \\
\text { bentuk media elektronik (transparansi/slide, CD/kaset } \\
\text { radio, VCD/kaset) }\end{array}$ & 35 & 3 & 1 & 1.13 & Rendah \\
\hline & Rata-rata & 58 & 15 & 5 & 1.32 & Rendah \\
\hline
\end{tabular}

Hasil analisis penilaian petani terhadap penyusunan materi penyuluhan pertanian didominasi oleh jawaban tidak setuju. Artinya dalam pemberian materi penyuluhan umumnya tidak menggunakan media apapun, baik media cetak maupun media elektronik. Hasil wawancara dengan petani di lapangan bahwa fasilitas terhadap media elektronik tersebut sulit didapatkan, karena yang menyediakan media khususnya media elektronik untuk kegiatan penyuluhan, yang menyiapkan peralatan tersebut adalah kelompok tani yang bersangkutan. .

"Kalau ka penyuluhan jiko diperlukan media model infokus, itu yang menyadion kelompok tani bukan penyuluh." (RW, Tanjung Munti, 24/04/2021).

Hal ini juga didukung oleh pernyataan penyuluh bahwa kegiatan penyuluh jarang menggunakan media apapun, seringkali penyuluhan dilakukan secara lisan. 
"Penyuluhan jarang yang mamakai buku atau infocus, tapi satiok materi dikecekan langsuang ka kelompok tani”. (RW, BPP Kec. Payakumbuh, 4/05/2021)

"Apapun materi penyuluhan yang disampaikan oleh seorang penyuluh, pertama-tama harus diingat bahwa materi tersebut harus selalu mengacu kepada kebutuhan yang telah dirasakan oleh masyarakat sasarannya" (Zuraidah, 2020)

\section{Persepsi Petani terhadap Penerapan Metode Penyuluhan Pertanian}

Forum penyuluhan dan temu lapang merupakan metode penyuluhan yang umumnya dijalankan oleh penyuluh. Hasil temuan menunjukkan penilaian kinerja Penyuluh terhadap penerapan metode penyuluhan dalam hal forum dan temu lapang di Kecamatan Payakumbuh terlihat pada Tabel 6.

Tabel 6. Persepsi Petani terhadap Penerapan Metode Penyuluh Pertanian

\begin{tabular}{clcccccc}
\hline \multirow{2}{*}{ No. } & \multicolumn{1}{c}{ Pernyataan } & TS & KS & S & \multirow{2}{*}{ Persepsi } & \multirow{2}{*}{ Keterangan } \\
\cline { 3 - 5 } & & $\mathbf{1}$ & $\mathbf{2}$ & $\mathbf{3}$ & & & \\
\hline \multirow{2}{*}{ Y5 } & Persepsi Petani terhadap Penerapan Metode & & & & & \\
X5.1 & $\begin{array}{l}\text { Penyuluhan Pertanian } \\
\text { Penyuluh menerapkan forum penyuluhan }\end{array}$ & 16 & 4 & 19 & 2.08 & Sedang \\
X5.2 & $\begin{array}{l}\text { Penyuluh menerapkan kegiatan temu teknis dan } \\
\text { temu lapang }\end{array}$ & 14 & 6 & 19 & 2.13 & Sedang \\
\hline & Rata-rata & 30 & 10 & 38 & 2.10 & Sedang \\
\hline
\end{tabular}

Hasil analisis menunjukkan penilaian petani terhadap metode penyuluhan katagori sedang. Dapat dilihat maksud dari forum penyuluhan di Kecamatan Payakumbuh dilakukan melalui kegiatan Rembug tani, yang menekankan mengenai permasalahan yang terjadi dalam pelaksanaan usahatani secara bersama-sama melalui suatu forum diskusi. Begitu juga dengan temu lapang, perbedaannya adalah temu lapang lebih dilakukan pada tempat terbuka dan dekat dengan pelaksanaan usahatani. Hal ini sesuai dengan pendapat (Heru, 2015) yang menyatakan bahwa "Pilihan seorang agen penyuluhan terhadap suatu metode tergantung pada tujuan khusus dan situasi kerjanya."

\section{Persepsi Petani terhadap Pengembangan Swadaya Petani}

Temuan penelitian terkait penilaian kinerja penyuluh terhadap pengembangan swadaya petani di Kecamatan Payakumbuh dapat dilihat pada Tabel 7.

Tabel 7. Persepsi Petani terhadap Pengembangan Swadaya Petani

\begin{tabular}{clccccc}
\hline \multirow{2}{*}{ No. } & \multicolumn{1}{c}{ Pernyataan } & TS & KS & S & \multirow{2}{*}{ Persepsi } & \multirow{2}{*}{ Keterangan } \\
\cline { 3 - 6 } & & $\mathbf{1}$ & $\mathbf{2}$ & $\mathbf{3}$ & & \\
\hline Y6 & Persepsi Petani terhadap Pengembangan Swadaya Petani & & & & & \\
X6.1 & Penyuluh berupaya menumbuhkan koperasi & 35 & 1 & 3 & 1.18 & Rendah \\
X6.2 & Penyuluh berupaya menumbuhkan kemitraan & 32 & 5 & 2 & 1.23 & Rendah \\
X6.3 & Penyuluh berupaya menilai kelas kemampuan & 7 & 0 & 32 & 2.64 & Sedang \\
\hline & Rata-rata & 74 & 6 & 37 & 1.68 & Rendah \\
\hline
\end{tabular}

Kinerja penyuluh mengenai penumbuhan koperasi dan kemitraan dinilai rendah oleh kelompok tani di Kecamatan Payakumbuh. Hal ini menunjukkan minimnya upaya penyuluh dalam menumbuhkan koperasi di kelompok tani. Berdasarkan temuan di lapangan, penyuluh belum secara maksimal dalam menggerakkan petani untuk menumbuhkan koperasi maupun kemitraan. Tetapi petani secara mandiri mencari mitra untuk menjual hasil pertanian dalam upaya meningkatkan pendapatan petani.

Dari hasil penilaian dua indikator di atas mengenai penumbuhan koperasi dan kemitraan berbanding terbalik dengan hasil penilaian kelas kemampuan kelompok tani, dimana katagori persepsi petani terhadap peran petani dalam kelas kemampuan masuk katagori sedang. Hal ini menujukkan bahwa kinerja penyuluh dalam menilai kelas kemampuan kelompok tani sudah baik sehingga nantinya akan memudahkan penyuluh dalam melakukan pengawalan dan pendampingan kelompok tani. Pengembangan swadaya petani akan menjadi lebih baik untuk mendorong pembagunan pertanian, 
apabila indikator pada Tabel 7 diwujudkan secara optimal. Hal ini sesuai dengan pendapat Heru, (2015); Lahidjun et al., (2020) yang berpendapat bahwa penyuluhan dapat menjadi efektif jika dipadukan dengan penelitian, penyediaan input dan pinjaman, serta pemasaran.

\section{Persepsi Petani terhadap Pengembangan Wilayah}

Tabel 8 terlihat bahwa indikator penilaian petani terhadap pengembangan teknologi, kelembagaan petani dan pengembangan usaha dan pendapatan petani rendah. Hal ini menunjukkan minimya upaya penyuluh dalam membantu petani.

Tabel 8. Persepsi Petani terhadap Pengembangan Wilayah

\begin{tabular}{|c|c|c|c|c|c|c|}
\hline \multirow{2}{*}{ No. } & \multirow{2}{*}{ Pernyataan } & TS & KS & $\mathbf{S}$ & \multirow{2}{*}{ Persepsi } & \multirow{2}{*}{ Keterangan } \\
\hline & & 1 & 2 & 3 & & \\
\hline Y7 & Persepsi Petani terhadap Pengembangan Wilayah & & & & & \\
\hline $\mathrm{X} 7.1$ & Penyuluh melakukan pengembangan teknologi & 22 & 4 & 13 & 1.77 & Rendah \\
\hline X7.2 & $\begin{array}{l}\text { Penyuluh melakukan pengembangan } \\
\text { kelembagaan petani }\end{array}$ & 30 & 3 & 4 & 1.23 & Rendah \\
\hline $\mathrm{X} 7.3$ & $\begin{array}{l}\text { Penyuluh melakukan pengembangan usaha dan } \\
\text { berupaya meningkatkan pendapatan petani }\end{array}$ & 21 & 4 & 14 & 1.82 & Rendah \\
\hline & Rata-rata & 73 & 11 & 31 & 1.61 & Rendah \\
\hline
\end{tabular}

Pengembangan teknologi berupa pengembangan teknologi baru yang didapatkan dari berbagai bantuan pemerintah. Selanjutnya untuk meningkatkan teknologi baru perlu adanya pelatihan yang diberikan oleh penyuluh pertanian. Hal ini didukung oleh pernyataan (Purwanto, 2020; Suyitman et al., 2009), yang menyatakan bahwa untuk meningkatkan indeks dan status keberlanjutan teknologi perlu penyebarluasan dan diseminasi teknogi melalui kursus, pelatihan dan penyuluhan pertanian yang ada di Indonesia, umumnya diberikan kepada kelompok tani.

Mengenai pengembangan kelembagaan petani dilakukan sejalan dengan adanya petnyuluhan pertanian dengan memotivasi petani untuk berpartisipasi dalam kelembagaan petani. Namun di kelompok tani Kecamatan Payakumbuh belum ditemui fenomena untuk pengembangan kelembagaan kelompok tani. Sama halnya dengan pengembangan usaha dan pendapatan petani. Umumnya petani secara mandiri dalam mengelola usahataninya tanpa bantuan dari pihak luar.

Melihat hal tersebut peran penyuluh harus memerlukan kemampuan pengetahuan yang luas tentang teknologi pertanian, begitu juga dalam mengawal lembaga petani. Hal ini sesuai dengan pendapat (Purwanto, 2020; Suhada, n.d.; Wibowo \& Haryanto, 2020) yang menyatakan bahwa penyuluhan pertanian memegang fungsi sebagai perantara ilmu dan teknologi baru yang telah dihasilkan dan siap diberikan kepada petani dilapangan sebagai orang yang akan membutuhkannya. Disamping itu, penyuluh dapat memberikan informasi bersifat progressif untuk melakukan perubahan dan penerapan inovasi baru.

\section{Persepsi Petani terhadap Pengembangan Profesi Penyuluh Pertanian}

Hasil penelitian yang diperoleh tentang penilaian kinerja penyuluh mengenai pengembangan profesi penyuluh pertanian di Kecamatan Payakumbuh dapat dilihat pada Tabel 9.

Tabel 9. Persepsi Petani terhadap Profesi Penyuluh Pertanian

\begin{tabular}{|c|c|c|c|c|c|c|}
\hline \multirow{2}{*}{ No. } & \multirow{2}{*}{ Pernyataan } & $\mathrm{TS}$ & KS & $\mathbf{S}$ & \multirow{2}{*}{ Persepsi } & \multirow{2}{*}{ Keterangan } \\
\hline & & 1 & 2 & 3 & & \\
\hline Y8 & Persepsi Petani terhadap Profesi Penyuluh Pertanian & & & & & \\
\hline $\mathrm{X} 8.1$ & $\begin{array}{l}\text { Penyuluh membuat karya tulis ilmiah tentang } \\
\text { kebijakan penyuluhan pertanian }\end{array}$ & 36 & 2 & 1 & 1.10 & Rendah \\
\hline X8.2 & $\begin{array}{l}\text { Penyuluh membuat karya tulis ilmiah tentang } \\
\text { kebijakan pembangunan pertanian }\end{array}$ & 37 & 1 & 1 & 1.08 & Rendah \\
\hline & Rata-rata & 73 & 3 & 2 & 1.09 & Rendah \\
\hline
\end{tabular}


Tabel 9 terlihat bahwa indikator mengenai karya tulis ilmiah yang dibuat oleh penyuluh pertanian belum dikenal oleh petani pada umumnya ataupun dirasakan petani sebagai agen perubahan. Hal ini menunjukkan bahwa penyuluh belum termotivasi untuk membuat suatu karya tulis ilmiah. Sehingga, kinerja yang dihasilkan belum optimal. Penyuluh lebih memilih beraktifitas kerja proyek segala sektor dibandingkan harus menulis suatu karya ilmiah. Hal ini sesuai dengan pendapat Sirnawati (2020) menyatakan bahwa pembinaan Profesionalisme Penyuluh Pertanian dalam Otonomi Daerah, menjadikan penyuluh tidak berpihak pada petani melainkan berpihak pada dinas subsektor dengan segala proyek yang ada.

\section{Persepsi Petani terhadap Pengembangan Hubungan Kerjasama dengan Lembaga Pemerintah dan Non Pemerintah}

Pada Tabel 10 terlihat bahwa hasil penilaian petani untuk pengembangan hubungan kerjasama tergolong rendah. Saat ini penyuluh belum cukup baik untuk mediasi kerjasama antara petani dengan lembaga non pemerintah berbentuk industri.

Tabel 10. Persepsi Petani terhadap Pengembangan Hubungan Kerjasama dengan Lembaga Pemerintah dan Non Pemerintah

\begin{tabular}{|c|c|c|c|c|c|c|}
\hline \multirow{2}{*}{ No. } & \multirow{2}{*}{ Pernyataan } & TS & KS & $\mathbf{S}$ & \multirow{2}{*}{ Persepsi } & \multirow{2}{*}{ Keterangan } \\
\hline & & 1 & 2 & 3 & & \\
\hline Y9 & $\begin{array}{l}\text { Persepsi Petani terhadap Pengembangan } \\
\text { Hubungan Kerjasama dengan Lembaga } \\
\text { Pemerintah dan Non Pemerintah }\end{array}$ & & & & & \\
\hline X9.1 & $\begin{array}{l}\text { Penyuluh melakukan pengembangan hubungan } \\
\text { kerjasama dengan koperasi }\end{array}$ & 37 & 1 & 1 & 1.08 & Rendah \\
\hline \multirow[t]{2}{*}{ X9.2 } & $\begin{array}{l}\text { Penyuluh melakukan pengembangan hubungan } \\
\text { kerjasama dengan pengusaha pertanian/industri }\end{array}$ & 34 & 4 & 1 & 1.15 & Rendah \\
\hline & Rata-rata & 71 & 5 & 2 & 1.12 & Rendah \\
\hline
\end{tabular}

Hal yang sama juga terjadi pada hubungan kerjasama petani dengan lembaga pemerintah belum terjalin optimal. Oleh karena itu, penting bagi kelompok tani untuk memperkuat organisasinya dengan membentuk lembaga koperasi sehingga kelompok tani dapat mengembangkan produksi pertaniannya.

\section{Hubungan antara Karakteristik Petani dengan Persepsi terhadap Kompetensi Penyuluh Pertanian di Kecamatan Payakumbuh}

Hasil uji korelasi Rank Spearman karakteristik petani terhadap kompetensi penyuluh pertanian di Kecamatan Payakumbuh secara statistik disajikan pada Tabel 11.

Tabel 11. Nilai Koefisen Korelasi dan Signifikansi Hubungan Karakteristik Petani dengan Tingkat Persepsi Petani terhadap Kompetensi Penyuluh Pertanian di Kecamatan Payakumbuh

\begin{tabular}{lcccccccccc}
\hline \multirow{2}{*}{ Karakteristik Petani } & \multicolumn{8}{c}{ Nilai Koefisien Korelasi dan Tingkat Signifikansi } \\
\cline { 2 - 10 } & Y1 & Y2 & Y3 & Y4 & Y5 & Y6 & Y7 & Y8 & Y9 \\
\hline Umur & 0.134 & 0.109 & 0.114 & 0.084 & -0.151 & 0.299 & 0.098 & 0.000 & 0.000 \\
Pendidikan Formal & 0.172 & 0.096 & -0.079 & 0.232 & -0.049 & 0.173 & 0.126 & 0.300 & $0.340 *$ \\
Status Kepemilikan Lahan & -0.033 & 0.260 & 0.200 & 0.092 & -0.018 & 0.029 & 0.212 & 0.247 & 0.271 \\
Pengalaman & -0.012 & -0.020 & 0.005 & -0.187 & 0.176 & -0.276 & -0.174 & -0.205 & -0.171 \\
\hline
\end{tabular}

\section{Keterangan:}

Y1 Persepsi Petani terhadap Kegiatan Utama Penyuluhan

Y2 Persepsi Petani terhadap Perencanaan Penyuluhan Pertanian

Y3 Persepsi Petani terhadap Program Penyuluhan Pertanian

Y4 Persepsi Petani terhadap Penyusunan Materi Penyuluhan Pertanian

Y5 Persepsi Petani terhadap Penerapan Metode Penyuluhan Pertanian

Y6 Persepsi Petani terhadap Pengembangan Swadaya Petani

Y7 Persepsi Petani terhadap Pengembangan Wilayah 
Y9 Persepsi Petani terhadap Pengembangan Hubungan Kerjasama dengan Lembaga Pemerintah dan Non Pemerintah

* korelasi signifikan pada taraf kepercayaan 95 persen $(a=0.05)$

** korelasi signifikan pada taraf kepercayaan 99 persen $(a=0.01)$

Data yang digunakan dalam analisis ini adalah data primer dimana karaktersitik petani yaitu umur, pendidikan formal, status kepemilikan lahan dan pengalaman berusahatani. Variabel tersebut akan dilihat hubungannya dengan 9 (sembilan) indikator kompetensi penyuluh pertanian. Berdasarkan hasil analisis pada Tabel 11 menunjukkan bahwa karakteristik petani pada faktor umur, status kepemilikan lahan dan pengalaman bertani tidak berhubungan nyata dengan tingkat persepsi petani terhadap kompetensi penyuluh pertanian. Kecuali, faktor pendidikan formal petani yang berhubungan nyata dengan tingkat persepsi petani terhadap pengembangan hubungan kerjasama dengan lembaga pemerintah dan non pemerintah. Hal ini menunjukkan bahwa semakin tinggi tingkat pendidikan petani maka persepsi petani terhadap pengembangan hubungan kerjasama dengan lembaga pemerintah dan non pemerintah semakin tinggi. Hal ini sejalan dengan hasil studi Ikhsan (2018) yang menunjukkan bahwa karakteristik umur, tingkat pendidikan formal, jumlah tanggungan, luas lahan garapan dan tingkat kekosmopolitan tidak berhubungan nyata dengan tingkat persepsi petani tentang kompetensi keujruen blang dalam pengembangan pertanian.

\section{Hubungan antara Karakteristik Petani dengan Persepsi terhadap Kompetensi Penyuluh Pertanian di Kecamatan Payakumbuh}

Hasil analisis yang ditampilkan pada Tabel 12 menunjukkan bahwa faktor-faktor pada variabel kegiatan penyuluhan yang diteliti yaitu keterlibatan petani mengikuti penyuluhan, intensitas dan interaksi petani dalam kegiatan penyuluhan memiliki hubungan positif dan nyata dengan tingkat persepsi petani terhadap kompetensi penyuluh pertanian, kecuali faktor penyusunan materi penyuluhan dan profesi penyuluh pertanian yang tidak memiliki hubungan nyata dengan tingkat persepsi petani. Hal ini dikarenakan kedua aktivitas ini dilaksanakan oleh penyuluh pertanian secara mandiri tanpa melibatkan petani secara langsung. Seperti dalam kegiatan pembuatan poster, brosur, booklet, maupun artikel ilmiah terkait pelaksanaan kegiatan penyuluhan di Kecamatan Payakumbuh.

Tabel 12. Nilai Koefisen Korelasi dan Signifikansi Hubungan Karakteristik Petani dengan Tingkat Persepsi Petani terhadap Kompetensi Penyuluh Pertanian di Kecamatan Payakumbuh

\begin{tabular}{lccccccccc}
\hline \multirow{2}{*}{$\begin{array}{c}\text { Kegiatan } \\
\text { Penyuluhan }\end{array}$} & \multicolumn{8}{c}{ Nilai Koefisien Korelasi dan Tingkat Signifikansi } \\
\cline { 2 - 10 } & Y1 & Y2 & Y3 & Y4 & Y5 & Y6 & Y7 & Y8 & Y9 \\
\hline Keterlibatan & $0.426^{* *}$ & $0.481^{* *}$ & $0.426^{* *}$ & 0.193 & 0.275 & $0.486^{* *}$ & $0.492^{* *}$ & 0.051 & 0.297 \\
Intensitas & $0.552^{* *}$ & $0.376^{*}$ & $0.350^{*}$ & 0.294 & $0.447^{* *}$ & $0.517^{* *}$ & $0.522^{* *}$ & 0.113 & $0.380^{*}$ \\
Interaksi & $0.459^{* *}$ & 0.197 & 0.129 & 0.267 & $0.437^{* *}$ & $0.403^{*}$ & $0.466^{* *}$ & 0.040 & 0.210 \\
\hline
\end{tabular}

Keterangan:

Y1 Persepsi Petani terhadap Kegiatan Utama Penyuluhan

Y2 Persepsi Petani terhadap Perencanaan Penyuluhan Pertanian

Y3 Persepsi Petani terhadap Program Penyuluhan Pertanian

Y4 Persepsi Petani terhadap Penyusunan Materi Penyuluhan Pertanian

Y5 Persepsi Petani terhadap Penerapan Metode Penyuluhan Pertanian

Y6 Persepsi Petani terhadap Pengembangan Swadaya Petani

Y7 Persepsi Petani terhadap Pengembangan Wilayah

Y8 Persepsi Petani terhadap Profesi Penyuluh Pertanian

Y9 Persepsi Petani terhadap Pengembangan Hubungan Kerjasama dengan Lembaga Pemerintah dan Non Pemerintah

* korelasi signifikan pada taraf kepercayaan 95 persen $(a=0.05)$

** korelasi signifikan pada taraf kepercayaan 99 persen $(a=0.01)$

Tingkat keterlibatan intensitas dan interaksi petani berhubungan nyata dengan persepsi petani terhadap kegiatan utama penyuluhan, pengembangan swadaya petani dan pengembangan wilayah. Hal ini 
menunjukkan bahwa semakin tinggi tingkat keterlibatan, intensitas dan interaksi petani dalam kegiatan penyuluhan maka tingkat persepsi petani terhadap kegiatan utama seperti praktek, bimbingan, pelatihan dan kunjungan semakin meningkat. Selanjutnya, faktor keterlibatan dan intensitas petani juga berpengaruh pada tingkat persepsi petani terhadap program dan penyusunan materi penyuluhan pertanian. Faktor ini berhubungan nyata dengan arah positif artinya semakin tinggi faktor keterlibatan dan intensitas petani, makan persepsi petani terhadap program penyuluhan dan penyusunan materi baik cetak maupun elektronik semakin meningkat.

Dalam kegiatan penyuluhan faktor yang berpengaruh nyata untuk tingkat persepsi petani terhadap pengembangan hubungan kerjasama dengan lembaga pemerintah dan non pemerintah adalah intensitas keterlibatan petani. Hal ini menunjukkan bahwa semakin sering intensitas pertemuan petani dengan penyuluh pertanian maka tingkat persepsi petani terhadap pengembangan hubungan kerjasama dengan lembaga pemerintah dan non pemerintah semakin tinggi.

\section{KESIMPULAN}

Petani memiliki persepsi rendah terhadap tingkat kompetensi penyuluh pertanian di Kecamatan Payakumbuh dalam kegiatan penyuluhan yang dilakukan. Penyuluh dinilai belum maksimal dalam menjalankan tugas dan tanggungjawabnya. Aktivitas terkait kegiatan utama penyuluhan, perencanaan penyuluhan, program penyuluhan, penyusunan materi penyuluhan, penerapan metode penyuluhan, pengembangan swadaya petani, pengembangan wilayah, profesi penyuluh pertanian serta pengembangan hubungan kerjasama dengan lembaga pemerintah dan non pemerintah perlu ditingkatkan agar dapat menunjang pengetahuan dan keterampilan petani.

Faktor-faktor yang berpengaruh nyata dengan tingkat persepsi petani terhadap kompetensi penyuluh pertanian adalah keterlibatan, intensitas dan interaksi petani pada kegiatan penyuluhan. Hal ini menunjukkan bahwa semakin sering keterlibatan, intensitas pertemuan dan interaksi petani dengan penyuluh pertanian maka tingkat persepsi petani terhadap kegiatan utama penyuluhan, perencanaan penyuluhan, program penyuluhan, penerapan metode penyuluhan, pengembangan swadaya petani, pengembangan wilayah, serta pengembangan hubungan kerjasama dengan lembaga pemerintah dan non pemerintah semakin tinggi. Kecuali persepsi petani terhadap penyusunan materi penyuluhan dan profesi penyuluh pertanian yang tidak memiliki hubungan nyata.

\section{DAFTAR PUSTAKA}

Afsar, N. (2019). Farmers perception of agricultural extension services in disseminating climate change knowledge. Sarhad Journal of Agriculture, 35(3), 942-947. https://doi.org/10.17582/ journal.sja/2019/35.3.942.947

Bahua, M. I. (2015). Penyuluhan dan Pemberdayaan Petani Indonesia. In Angewandte Chemie International Edition, 6(11), 951-952.

Banunaek, M. F., Suminah, \& Karsidi, R. (2020). Pengaruh Faktor Individu dan Faktor Psikologi Penyuluh Terhadap Kinerja Penyuluh Pertanian Lapangan (PPL) di kabupaten Boyolali Propinsi Jawa Tengah. PARTNER, 25(2), 1415-1423. https://jurnal.politanikoe.ac.id/index.php/ $\mathrm{jp} / \mathrm{article} / \mathrm{view} / 473$

Gitosaputro, S., \& Listiana, I. (2018). Dinamika Penyuluhan Pertanian: dari Era Kolonial sampai dengan Era Digital. In CV. Anugrah Utama Raharja.

Hanan, A., Mukhlis, \& Maulina, N. E. (2019). Buku Pintar Penyuluhan. Dinas Pertanian dan Perkebunan Aceh.

Hasan, I. (2000). Analisis Produksi Kopi Di Desa Mbenti Kecamatan Minyambow Kabupaten Manokwari. Universitas Cendrawai.

Heru, P. (2015). Potensi Pengembangan Peternakan Sapi Potong di Kecamatan Tanjung Bintang Kabupaten Lampung Selatan. Jurnal Ilmiah Peternakan Terpadu, 3(4).

Jalaluddin, \& Adjie, G. (2020). Analisis Kinerja Penyuluh Pertanian dalam Memberdayakan dan Memandirikan Petani Padi (Oryza Sativa) Sawah di Kelurahan Kempas Jaya Kecamatan Kempas Kabupaten Indragiri Hilir. Jurnal Selodang Mayang, 6(2), 78-83. https://ojs.selodangmayang.com/index.php/bappeda/article/view/167 
Lahidjun, N. M. R., Rauf, A., \& Saleh, Y. (2020). Evaluasi Kinerja Penyuluh Pertanian pada Petani Hortikultura di kecamatan Limboto. AGRINESIA, 5(1), 46-54. https://ejurnal.ung.ac.id/ index.php/AGR/article/view/11816

Mardikanto, Tatok, \& Soebianto, P. (2013). Pemberdayaan Masyarakat Dalam Perspektif Kebijakan. Alfabeta Bandung.

Mbeche, R. M., Mose, G. N., \& Ateka, J. M. (2021). The Influence of Privatised Agricultural Extension on Downward Accountability to Smallholder Tea Farmers. Journal of Agricultural Education and Extension, O(0), 1-22. https://doi.org/10.1080/1389224X.2021.1932538

Mulieng, Z. F., Amanah, S., \& Asngari, P. S. (2018). Persepsi petani terhadap kompetensi penyuluh pertanian tanaman pangan di Kabupaten Aceh Utara. Jurnal Penyuluhan. http://journal.ipb.ac.id/index.php/jupe/article/view/17556

Nettle, R. (2021). Factors associated with farmers' use of fee-for-service advisors in a privatized agricultural extension system. Land Use Policy, 104. https://doi.org/10.1016/j.landusepol. 2021.105360

Nurfaidah, B. Y. D., \& Rusdiyana, E. (2020). Perception of field agricultural extension on the implementation of the law on protection and empowerment of farmers (republic of Indonesia law number 19 of 2013) in grobogan regency. IOP Conference Series: Earth and Environmental Science, 456(1). https://doi.org/10.1088/1755-1315/456/1/012083

Nurmayasari, I., Viantimala, B., Gultom, D. T., Yanfika, H., \& Mutolib, A. (2020). Partisipasi dan Kepuasan Petani terhadap Kinerja Penyuluh Pertanian di Kecamatan Palas Kabupaten Lampung Selatan. Mimbar Agribisnis: Jurnal Pemikiran Masyarakat Ilmiah Berwawasan Agribisnis, 6(1), 448-459. http://repository.lppm.unila.ac.id/18090/

Purukan, B. N., Nayoan, H., \& Pangemanan, F. N. (2021). Disiplin Pegawai Dalam Meningkatkan Kualitas Pelayanan Publik di Kantor Kecamatan Tikala. Jurnal Governance, 1(1), 1-8.

Purwanto, A. B. A. (2020). Analisis Kinerja Penyuluh Pertanian Melalui Pemanfaatan Media Internet (Studi Kasus: Kecamatan Percut Sei Tuan Kabupaten Deli Serdang). repository.umsu.ac.id. http://repository.umsu.ac.id/handle/123456789/11264

Saridewi, T., Ilhami, W., \& Junaidi, E. (2020). Farming Productivity, Farmers' Perception and Satisfaction to Agricultural Extension Worker in Garut Regency. IOP Conference Series: Earth and Environmental Science, 518(1). https://doi.org/10.1088/1755-1315/518/1/012050

Setyasih, E. P., Watemin, \& Utami, P. (2020). Peran Penyuluh Pertanian terhadap Kinerja Kelompok Tani di Kecamatan Sumbang, Kabupaten Banyumas. Prosiding Seminar Nasional Fakultas Pertanian "Pembangunan Pertanian Berkelanjutan Dalam Perspektif Teknologi, Sosial, Dan Ekonomi," 283-288.

Sirnawati, E. (2020). Urgensi Penyuluhan Pertanian Baru di Indonesia. In IAARD Press.

Suhada, A. (n.d.). Pengaruh Kepemimpinan, kompetensi dan motivasi terhadap kinerja penyuluh pertanian di Kota Sukabumi, Provinsi Jawa Barat. Repository.Uinjkt.Ac.Id. http://repository. uinjkt.ac.id/dspace/handle/123456789/55109

Suyitman, S., Sutjahjo, C., Herison, \& Muladno. (2009). Status Keberlanjutan Wilayah Berbasis Peternakan di Kabupaten Situbondo untuk Pengembangan Kawasan Agropolitan. Jurnal Agro Ekonomi, 27(2), 165-191.

Sylla, A. Y., Al-Hassan, R. M., Egyir, I. S., \& Somuah, H. A. (2019). Perceptions About Quality of Public and Private Agricultural Extension in Africa: Evidence from Farmers in Burkina Faso. Cogent Food and Agriculture, 5(1). https://doi.org/10.1080/23311932.2019.1685861

Undang Undang RI. (2006). Undang-Undang Republik Indonesia Nomor 16 Tahun 2006 Tentang Sistem Penyuluhan Pertanian, Perikanan dan Kehutanan. Undang Undang Republik Indonesia Nomor 16 Tahun 2006, 1-39. 
Wibowo, H. T., \& Haryanto, Y. (2020). Kinerja Penyuluh Pertanian dalam Masa Pandemi Covid-19 di Kabupaten Magelang. Jurnal Penelitian Peternakan Terpadu, 2(2), 79-92. http://jurnal. polbangtanyoma.ac.id/index.php/jppt/article/view/286

Widakdo, D., Holik, A., \& Iska, L. N. (2021). Efek Usia dan Tingkat Pendidikan terhadap Kinerja Tenaga Bantu Penyuluh Pertanian. Jurnal Penyuluhan.https://jurnal.ipb.ac.id/index.php/jupe/ article/view/31614

Zulfikar, Amanah, S., \& Asngari, P. (2018). Persepsi Petani terhadap Kompetensi Penyuluhan Pertanian Tanaman Pangan di Kabupaten Aceh Utara. Jurnal Penyuluhan, 14(1).

Zuraidah, S. (2020). nalisis Persepsi Petani Terhadap Kinerja Penyuluh Pertanian di Desa Amplas Kecamatan Percut Sei Tuan Kabupaten Deli Serdang. repository.umsu.ac.id. http://repository.umsu.ac.id/handle/123456789/14302 